\title{
The Life and Work of Professor Riehm from a Participant's Perspective
}

H. Gadner

Bibliography DOI http://dx.doi.org/ $10.1055 / \mathrm{s}-0033-1337953$ Klin Padiatr 2013; 225 (Suppl. 1): S3-S4 (c) Georg Thieme Verlag KG Stuttgart · New York ISSN 0300-8630

\section{Correspondence}

Prof. Dr. Dr. h.c. Helmut Gadner

A-3400 Klosterneuburg Steinwandgasse 10 a

helmut.gadner@ccri.at
The therapy for leukaemia in children has experienced an encouraging development during the past decades and the paediatric haemato- oncologists can be proud of the fact, that today almost $90 \%$ of the children with acute lymphoblastic leukaemia can be cured. The impulse for this development was the merit of a number of extraordinary personalities, who devoted their efforts in the late 1960s and in the 1970s with great commitment to the vision of curing leukaemia in children and adolescents. One of them is Professor Dr. Hansjörg Riehm, who gained worldwide recognition for his decisive and successful efforts in the improvement of leukaemia therapy. After completing a 2-year research project at the Memorial Sloan-Kettering Cancer Center in New York, in which Dr. Riehm investigated how tumor cells develop resistance to cytostatics, he returned by the end of 1969 to the Paediatric Haematology/Oncology Department of the Free Universität in West Berlin. In his luggage he was carrying a container with neuroblastoma cells in culture, with which he obviously wished to continue his research work in Berlin. This did not happen, however, as the cells unfortunately died within a few weeks of his return.

Inspired by his experience in the United States, he immediately directed his efforts to the elaboration of a new treatment concept for children suffering from leukaemia according to his own ideas, and, thus, became a highly regarded teacher and mentor for his associates in the team of medical doctors and laboratory assistants. Facing discouragement from failures in previous leukaemia therapies this highly committed group, to which the author also belonged, had already eagerly awaited the return of Dr. Riehm, in hopes of making significant progress. Then, we welcomed him back like an Olympic hero and listened to him enthusiastically. Often we discussed his ideas about new treatment possibilities late into the night. One of his main aims was to demonstrate, that leukaemia in children can be cured. He realized that any breakthrough can only be achieved when the intensity of induction therapy can be raised to the limits of individual tolerance. With this idea in mind, he contributed decisively to the revolutionary turnaround in childhood leukaemia treatment. In this manner, the West Berlin Study for the treatment of acute lymphoblastic leukaemia was born within a few weeks and subsequently applied from 1970 to 1976, results of which showed for the first time some $60 \%$ cure rate [1].

As it was to be anticipated, at the beginning, the estimation of a possible cure triggered consider- able animosity, initially from paediatricians and haemato-oncologists in West Berlin and then throughout the medical profession in the Federal Republic of Germany. Thus, during a haematooncological congress in Cologne, to which Professor Riehm had been invited to present a paper, most of the participants left the hall in disbelief of a possible cure after he had commenced his lecture. During various meetings with highly regarded medical colleagues in the United States, to which I accompanied Professor Riehm, great interest and surprise about the good results were initially noticed, but soon turned into scepticism which led to the fact that the West Berlin treatment concept and its encouraging results never being mentioned in any American publications and presentations. The breakthrough came in 1980, when Professor Riehm was able to publish the details in an American journal [2].

All the above mentioned events were both a heavy burden for Professor Riehm and the members of the team, but also resulted in motivation to continue researching. An unanticipated challenge, however, arose as a result of previously unseen side effects and partially hazardous complications from the therapy. We learned from experience how to deal with these phenomena with effective countermeasures and appropriate care. As a consequence, Professor Riehm claimed in his first results report in January 1977, that the initial treatment may only be applied in special departments by appropriately experienced teams [1].

Due to his professional competence and power of conviction, as well as an uncompromising personal effort for every single child suffering from cancer, Professor Riehm was soon able to concentrate the cases of childhood leukaemia within the whole of West Berlin into his own department. The press dissemination of the successes of his battle against childhood cancer resulted in a growing recognition also from the Federal States of Western Germany. Gradually the University Hospitals of Frankfurt-on-Main and Muenster in Westphalia decided to participate in the WestBerlin treatment protocol. I remember the visit of Professor Schellong coming from Muenster for reaching an agreement about the first randomised study. After a couple of days at Professor Riehm's sick bed, we achieved the launch for the BFM Protocol (BFM Study 1976-1979), which turned out to be the so-called 'backbone' of leukaemia therapy in the history of paediatric oncology, and then subsequently became an essential component for leukaemia therapies in the later 'GPOH' Studies. During the 1980s and 1990s, 
Pan-European collaboration was achieved and led to the creation of the international 'BFM Family' first in Europe, then in South America, and beyond. The 'BFM family' also enabled a strong networking with the American university hospitals.

As an early student and associate from the very beginning, I feel the need to write this editorial on the occasion of the $80^{\text {th }}$ birthday of Professor Hansjörg Riehm. The following articles in this journal bare witness, that his widely scattered alumni have emphatically advanced his ideas and have been devoting themselves to further ongoing developments in the treatment of childhood cancer.

Ad multos annos Helmut Gadner

\section{References}

1 Riehm H, Gadner H, Welte K. Die West-Berliner Studie zur Behandlung der aktuen lymphoblastischen Leukämie des Kindes - Erfahrungsbericht nach 6 Jahren. Klin Paediatr 1977; 189: 89-102

2 Riehm H, Gadner H, Henze G. The Berlin Childhood Acute Lymphoblastic Leukemia Therapy Study, 1970-1976. Am J Pediatr Hematol Oncol 1980; 2: 299-306 